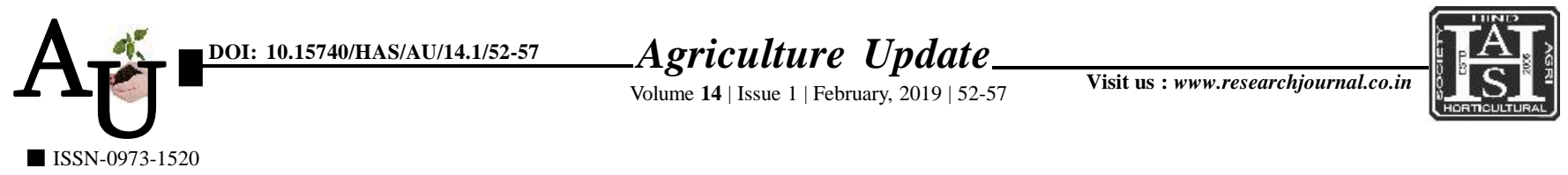

\title{
Research Article: Production and marketing constraints analysis of kinnow growers in Himachal Pradesh
}

\author{
Sanjeev Kumar and Raj Rani Sharma
}

Article Chronicle: Received : 08.11.2018;

Revised :

07.01.2019;

Accepted :

12.01.2019

KeY Words :

Kinnow, Marketing problems, Marketing strategy, Multistage sampling

\section{Author for correspondence :}

\section{Sanjeev Kumar}

Department of Social

Sciences, Dr. Y.S. Parmar

University of

Horticulture and

Forestry, Nauni, Solan

(H.P.) India

Email: sharmask93@

rediffmail.com

See end of the article for

authors' affiliations
SUMMARY : The present study was conducted in Kangra district of Himachal Pradesh during 2017-18. A multistage sampling technique was adopted to select the ultimate sample of size 100 kinnow growers in total. The results of the study revealed that overall major production problems faced by the farmers in the study area were high cost of plant protection chemicals followed by the problem of stray animals, limited availability of FYM, shortage of skilled labour, higher wage rate and non- availability of labour at peak operation time as reported by $48.00,46.00,44.00,38.00,36.00$ and 33.00 per cent respondents in the study area, respectively. In case of marketing problems, major problem were low prices for the produce, deduction of more charges by various marketing agencies, high transportation charges and higher wage rates as reported by $72.00,53.00,49.00$ and 49.00 per cent of respondents, respectively. The results also revealed that shortage of skilled labour, higher wage rates and problem of stray animals were found to be statistically significant production problems while in case of marketing related problems, higher wage rate, non-availability of labour at peak operation time, higher prices of packing material and high transportation charges were found to be statistically significant problems. It was found that the availability of inputs on time and proper marketing strategy for marketing of produce could increase the production and income from the produce in the study area.

How to cite this article : Kumar, Sanjeev and Sharma, Raj Rani (2019). Production and marketing constraints analysis of kinnow growers in Himachal Pradesh. Agric. Update, 14(1): 52-57; DOI : 10.15740/HAS/AU/14.1/ 52-57. Copyright@ 2019: Hind Agri-Horticultural Society. 